http://dx.doi.org/10.12775/szhf.2019.033

\author{
Damian Mrugalski OP \\ Dominican School of Philosophy and Theology, Kraków \\ E-MAIL:MNICHOP@GMAIL.COM \\ ORCID: 0000-0002-8689-9832
}

\title{
Plato Read Moses and (Mis-)Understood. The Middle Platonic Context in Which the Creatio Ex Nihilo Doctrine Was Devised
}

\section{Introduction}

In the metaphysical prelude to the famous myth of the Demiurge that we find in the Timaeus, Plato poses the following question to his listeners:

Now as to the whole heaven or order of the universe - for whatsoever name is most acceptable to it, be it so named by us - we must first ask concerning it the question which lies at the outset of every inquiry, whether did it exist eternally,

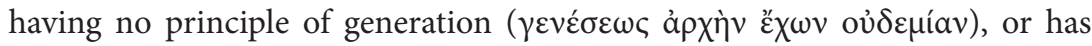

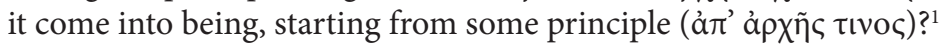

\footnotetext{
1 Plato, Timaeus, 28b.
} 
According to Plato, the world "has come into being ( $\gamma \varepsilon \dot{\gamma} \gamma o v \varepsilon v)$ for it is visible and tangible and has a body" ${ }^{2}$, and such things - as opposed to ideas - are in a permanent process of becoming. Furthermore, there is a cause of their generation $^{3}$. This seemingly unambiguous statement made by the philosopher of Athens has been interpreted in various ways by philosophers whom we call the Middle Platonists today and who made their allegorical comments to Plato's Timaeus in the first three centuries A.D. ${ }^{4}$ Obviously, there must have

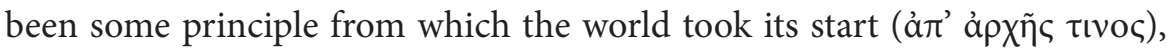
but the question of whether it was created in time, or whether it has existed eternally as created, triggered a heated debate among thinkers, not only pagan, but also Jewish and Christian, who were well acquainted with the theses of Middle Platonic philosophers. In this context, the question of matter also arose. Is it one of the cosmogenic principles (à $\rho \chi \alpha i)$, or was it created by God and then moulded and transformed into this visible world?

One of the classic studies on the origins of the creatio ex nihilo doctrine is the book Schöpfung aus dem Nichts by Gerhard May ${ }^{5}$, which has come under considerable criticism in some circles ${ }^{6}$, whereas in others it has been received

2 Ibidem.

${ }^{3}$ Cf. ibidem, 27d; 28c.

4 On the doctrines of respective Middle Platonists and the Middle Platonic interpretation of Timaeus see Salvatore Lilla, Introduzione al Medio platonismo (Roma: Istituto Patristico Augustinianum, 1992); John Dillon, The Middle Platonists: 80 B.C. to A.D. 220 (Ithaca: Cornell University Press, 1996); Franco Ferrari, "L'esegesi medioplatonica del Timeo: metodi, finalità, risultati”, in: Il Timeo. Esegesi greche, arabe, latine, ed. Francesco Celia, Angela Ulacco (Pisa: Plus-Pisa University Press, 2012), 81-131.

5 Cf. Gerhard May, Schöpfung aus dem Nichts: Die Entstehung der Lehre von der creatio ex nihilo (Berlin: Walter de Gruyter, 1978). This article will refer to the improved English version of the same monograph: Gerhard May, Creatio ex Nihilo: The Doctrine of 'Creation out of Nothing' in Early Christian Thought, transl. A. S. Worrall (London: T\&T Clark International, 2004).

6 The critics of May's thesis prove, sometimes perhaps through excessive emphasis, that the first verses of Genesis speak of creation out of nothing, and that the presence of this doctrine in the Bible is confirmed by the statement in 2 Mac. 7:28, which states explicitly that God

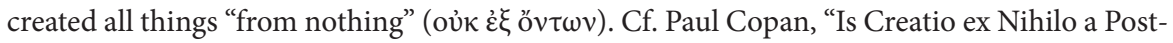
Biblical Invention? An Examination of Gerhard May's Proposal”, Trinity Journal 17 (1996): 77-93; John C. O’Neil, "How Early is the Doctrine of Creatio ex Nihilo?", Journal of Theological Studies 58 (2002): 449-465; Paul Copan, William L. Craig, Creation Out of Nothing: A Biblical, Philosophical, and Scientific Exploration (Grand Rapids: Baker Academic, 2004). 
with appreciation, although sometimes corrected and supplemented ${ }^{7}$. The author argues that the concept of creation out of nothing is closely related to the concept of the transcendence of God. Only when God is recognized as the supreme, but also the sole principle of the whole reality, which embodies infinite creative power, there is no need to propound another principle of creation which the Platonists consider to be matter ${ }^{8}$. However, as May notes, Christian thinkers of the first two centuries, especially those philosophically educated, echoed sometimes unthinkingly, Plato's theses of creation from eternal matter. However, they only started to talk about creatio ex nihilo when they had to stand against the spread of gnosticism, since the latter deformed the Christian doctrine of creation by linking matter with evil, which was largely based on the cosmology of the Platonists ${ }^{9}$. It was only the rejection of Platonism and the awareness of its pernicious influence that made it possible to finally and permanently introduce the concept of creation out of nothing into Christian doctrine.

The aim of this article is to demonstrate that the emergence of the creatio ex nihilo doctrine is part of the philosophical debate on the first metaphysical principles mentioned above, which did not necessarily mean the rejection of Platonism. Therefore, we will not search for the oldest texts that could suggest the presence of the creation out of nothing doctrine on the grounds

7 Many scholars agree with May that none of the biblical texts speak directly of creatio ex nihilo. Some of them, however, may suggest a doctrine of creation out of nothing indirectly, and it is these texts that became the source of inspiration for the subsequent Jewish and Christian commentaries postulating this doctrine. Cf. Frances Young, "Creatio Ex Nihilo: A Context for the Emergence of the Christian Doctrine of Creation", Scottish Journal of Theology 44 (1991): 139-152; Maren R. Niehoff, "Creatio ex Nihilo Theology in Genesis Rabbah in Light of Christian Exegesis", Harvard Theological Review 99 (2006): 37-64; Ernan McMullin, "Creation ex Nihilo: Early History", in: Creation and the God of Abraham, ed. David B. Burrell et al. (Cambridge: Cambridge University Press, 2010), 11-23; Markus Bockmuehl, "Creatio ex Nihilo in Palestinian Judaism and Early Christianity", Scottish Journal of Theology 65 (2012): 253-270.

8 Cf. May, Creatio ex Nihilo, 73-75.

9 Ibidem, 83-84. It ought to be added, however, that May also proves, which is in a way a historical paradox, that the first known Christian thinker who spoke of creation out of nothing in the strict sense was in fact a Gnostic - Basilides ( $2^{\text {nd }}$ century A.D.). However, as the scholar suggests, he could draw on some anti-Platonist source which was known in Syria, where he came from. Tatian and Theophilus Antiochal, who subsequently also preached the doctrine of creatio ex nihilo, also worked in that milieu. Cf. ibidem, 76-83. 
of Judaism or Christianity, as other researchers have done so, but we will discuss what Gerhard May left out in his monograph. Using a few examples, in particular the statements made by Clement of Alexandria and Origen, we will try to demonstrate that thinkers who remained under strong influence of Platonism, and assumed the concept of radical transcendence and the omnipotence of God, could talk about the creation of the world out of nothing (or not) depending on how they understood Platonic metaphysical principles. Their theses did not necessarily appear in the context of antignostic polemics - as May suggests - but they were voiced in the discussions on the first metaphysical principles held by Middle Platonists from the first to the third century A.D.

\section{The Middle Platonists Debate on the First Principles}

A brief synthesis of the Middle Platonists' metaphysics is an extremely difficult task, because we are not dealing here with a uniform system, but with a multitude of various commentaries concerning various theses put forth by Plato, which appeared in his dialogues, as well as those remembered from his unwritten teachings. However, what connected each of the philosophers of this movement was, paradoxically, an attempt to attribute to the author of the dialogues a unified philosophical system in which one can notice a certain type of "theologization" of the sphere of the intelligible being ${ }^{10}$. Therefore, although the Middle Platonists spoke of three principles of reality which are God, ideas, and matter, they believed that God is ultimately the supreme and transcendent cause of everything. Ideas, on the other hand, are His thoughts, and matter is a passive and indefinite material which, as it is devoid of any forms, is actually a "non-being".

10 Cf. Franco Ferrari, "Metafisica e teologia nel medioplatonismo", Rivista di storia della filosofia 70 (2015): 321-323, where the author lists a few other features common to the systems of Middle Platonists. These are, among other things, the establishment of ontological hierarchies; predilection for the theses proposed in Timaeus and its interpretation in the light of Plato's other dialogues, or the description of the First Divine Mind in Aristotle's categories, that is, as "The First Unmoved Mover" or "Self-Thinking Thought". 
The first thinker we know to have identified Platonic ideas with the thoughts of God was a Jew, Philo of Alexandria ( $1^{\text {st }}$ century B.C. $/ 1^{\text {st }}$ century A.D. $)^{11}$. This identification was probably linked to the radical monotheism that characterized Judaism, which did not allow the existence of any other, more transcendent, principle of all reality above God. Ideas, although eternal and unchangeable ${ }^{12}$, are therefore transferred by Philo to a lower ontological level, for their existence is dependent on God. Moreover, to further emphasize God's transcendence, the thinker of Alexandria states that God, being the Mind of all things ( $\delta \tau \tilde{\omega} v$ ö $\lambda \omega v$ voṽc), "is better than Good and

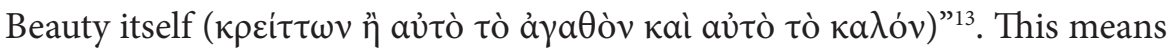
that He somehow surpasses the highest metaphysical principle Plato spoke

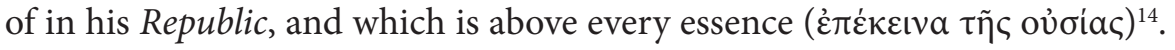
Elsewhere, Philo defines God as more transcendent than the One and the Monad $^{15}$. As far as matter is concerned, the Alexandrian also characterizes it in the Platonic way, as he speaks of it as of a substance passive and devoid of quality ${ }^{16}$. God acts upon such a material substrate with His power, the Logos, and transforms it into a beautiful and harmonious visible world ${ }^{17}$. Although Philo does not say it directly, some of his statements may suggest that matter, before it took visible form, was first created ${ }^{18}$, or that God called up

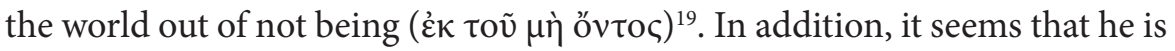
able to notice the difference between demiurgic and creative activity since he

${ }_{11}$ Cf. Philo, De opificio mundi, 15-20, 24-26. See also David T. Runia, "A Brief History of the Term Kosmos Noetos from Plato to Plotinus", in: Traditions of Platonism. Essays in Honour of John Dillon, ed. John J. Cleary (Aldershot: Ashgate, 1999), 154-158.

12 Cf. Philo, De mutatione, 267; idem, Quod sit Deus, 32.

13 Cf. idem, De opificio mundi, 8. See also idem, Legatio ad Gaium, 5.

14 Cf. Plato, Respublica, 509b.

15 Cf. Philo, De contemplatione 2; idem, De Praemiis 40. For more on the transcendence of God in Philo, see Damian Mrugalski, Il Dio trascendente nella filosofia alessandrina giudaica e cristiana: Filone e Clemente (Roma: Angelicum University Press, 2013), 63-89.

${ }_{16}$ Cf. idem, De opificio mundi, 21-22. See also Plato, Timaeus, 49a-50e.

17 Cf. idem, De opificio mundi, 20-21.

18 Cf. ibidem, 29. It says that God first created the immaterial heavens and the invisible

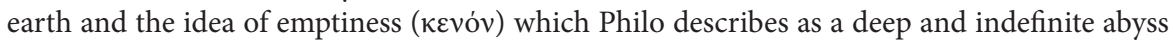

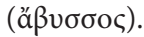

19 Cf. Philo, De vita Mosis, II, 267. See also idem, De specialibus legibus, IV, 187; idem, Legum Allegoriae, III, 10; idem, Quod Deus sit, 119; idem, De migratione Abrahami, 183. 
states that "God made things which before were not, not just handling mate-

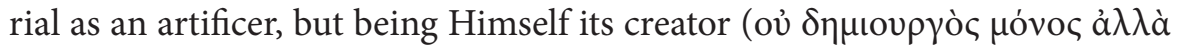

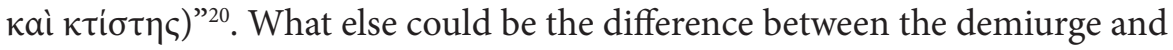
the creator if not creation out of matter and creation out of nothing? Philo himself, however, does not clearly explain the essence of his terminological distinction ${ }^{21}$.

What Gerhard May did not take account of in his monograph was the fact that the creation of matter was discussed by another Middle Platonist who lived at the same time and place as Philo, namely Eudorus of Alexandria. He states that "for some people the forms ( $\tau \dot{\alpha}$ $\varepsilon i \delta \eta)$ are the cause of essence ( $\tau$ ov $\tau i$ ), while for those who know, the One is the cause also for the matter

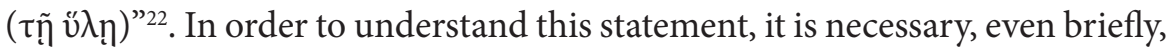
to refer to the doctrine of the first principles that emerges from Eudorus' preserved fragments. In line with Plato's unwritten teachings ${ }^{23}$, he believed that the One and the Indefinite Dyad are the supreme metaphysical principles. The One is the cause of the forms of ideas, while the Dyad is, as it were, intelligible matter, i.e. it plays the function of matter in ideas ${ }^{24}$. Due to these two principles, the problem of unity and multiplicity of the intelligible world is

20 Idem, De somniis, I, 76.

21 Although G. May does not agree to attribute the creatio ex nihilo doctrine to Philo, mainly because of the lack of clear statements about the creation of matter (cf. May, Creatio ex Nihilo, 10-20), other researchers announce Philo as the inventor of the philosophical doctrine of the creation out of nothing. Cf. Giovanni Reale, "Filone di Alessandria e la prima elaborazione filosofica della dottrina della creazione", in: Paradoxos politeia. Studi patristici in onore di Giuseppe Lazzati, ed. Raniero Cantalamessa et al. (Milano: Vita e Pansiero, 1979), 247-287. There are also those who see a kind of modification of Platonic doctrine in Philo's writings (towards creatio aeterna), although they do not find grounds to consider him the inventor of the creatio ex nihilo doctrine. See Gregory E. Sterling, "The Most Perfect Work: The Role of Matter in Philo of Alexandria", in: Creation "ex nihilo": Origins, Development, Contemporary Challenges, ed. Gary A. Anderson et al. (Notre Dame: University of Notre Dame Press, 2017), 99-118.

22 Eudorus, Fr 2 (ed. Vimercati, 78-80).

23 The preserved testimonies of Plato's unwritten teachings are collected and commented on by Marie-Dominique Richard, Lenseignement oral de Platon. Une nouvelle interprétation du platonisme (Paris: Cerf, 2005); Giovanni Reale, Per una nuova interpretazione di Platone alla luce delle "dottrine non scritte" (Milano: Bompiani, 2010).

${ }^{24}$ Cf. Eudorus, Fr 2-3 (ed. Vimercati, 78-80). See also Dillon, The Middle Platonists, $126-129$. 
explained. When the One acts upon the Dyad, it makes a multitude of forms (ideas) come into being which, in turn, become a formal cause for the beings of the material world. However, what makes Eudorus unique when compared to other Platonists who knew Plato's unwritten teachings is that he positions an even more transcendent principle above the opposition of One - Dyad which he also calls the One ${ }^{25}$. The latter is the absolute cause of absolutely everything. The Alexandrian derives his doctrine not only from Plato's unwritten teachings but also from a certain interpretation of Pythagorean philosophy:

Also in another sense [the Pythagoreans] claimed that the One is the principle of all things, because both matter and all beings were born from It. According

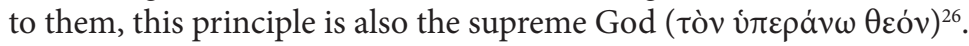

The One, which is the supreme being, and the highest God at the same time, is the origin of all things: both the superior metaphysical principles, i.e. the One and the Dyad, as well as material beings, including matter. Eudorus is aware that this interpretation would not have been accepted by other Platonists who claim that matter is eternal, although they also rely on Plato's unwritten teachings. That is why, in the text quoted above (Fr. 2), he adds: "for those who know ( $\tau$ oĩ $\delta \dot{\varepsilon} \varepsilon$ " $\delta \varepsilon \sigma \mathrm{l}$ ), the One is the cause also for the matter". If this is the case, Eudorus seems to have been the first thinker to introduce the concept of creatio ex nihilo along with the concept of radical transcendence of supreme God. According to him, matter is created by the supreme God - the transcendent One.

In the light of such understood teaching of the first principles, the statements by Philo of Alexandria, who was active in the same city and at the same time, take on significance of a different kind. As we have seen above, he also considered God to be more transcendent than the One or the Monad ${ }^{27}$. And,

25 Cf. Eudorus, Fr. 3 (ed. Vimercati, 80); idem, Fr. 5 (ed. Vimercati, 82).

${ }^{26}$ Idem, Fr. 4 (ed. Vimercati, 80).

${ }^{27}$ It is worth noting here that also Eudorus uses the term "Monad" to refer to the One (the lower One which is opposed to the Dyad). So, together with Philo, he can also say with that the supreme God is more transcendent than the One or the Monad. Cf. Eudorus Fr. 5 (ed. Vimercati, 82). 
if so, then his statement that God is "not only the demiurge, but also the creator" may indeed point to creatio ex nihilo. Absolutely everything comes from God: intelligible and material beings, archetypes of the world and matter, just as Eudorus claims.

It may seem that the Middle Platonists of the second century A.D., i.e. later than Philo and Eudorus of Alexandria, accept that that matter is eternal and uncreated because they attribute the same qualities to it as Plato did in Timaeus $^{28}$. However, one should be careful when interpreting this kind of statements because in the works by these philosophers the question of matter often arises in the context of the dispute about eternity of the world which we mentioned in the introduction. It turns out that even the word "ungenerated"

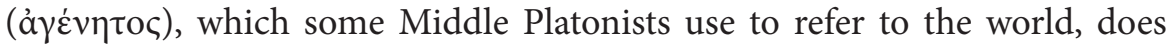
not necessarily imply that the world is eternal as God is ${ }^{29}$. For Albinus, for

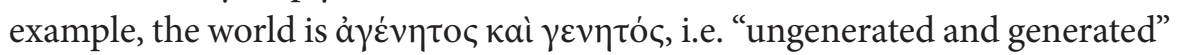
all at the same time. "Ungenerated", because it exists everlastingly in the temporal order, "generated", because it has the external principle of its generation $\left(\gamma \varepsilon v \varepsilon \dot{\varepsilon} \sigma \omega \varsigma \dot{\alpha} \rho \chi \eta^{\prime}\right)^{30}$. This principle, that is God, is called by Albinus as an "older" ( $\pi \rho \varepsilon \sigma \beta v \tau \varepsilon \rho \alpha v)$ and eternal cause in the primordial sense $(\pi \rho \omega \dot{\tau} \omega \varsigma)^{31}$. Although the preserved fragments of the works by this philosopher's do not speak of it, it is possible that he understood matter as one of the principles of the origin of the world which is first created by God and then ordered and transformed into a visible world. This sequence is obviously about a logical or ontological order rather than a chronological order. For, according to Albinus, the world exists eternally and yet God is its supreme cause: ungenerated, older, and truly eternal.

Calvenus Taurus also speaks in a similar vein. He considers as generated something whose being comes from outside, that is, from God, although

${ }^{28}$ Cf. Plato, Timaeus, 49a-50e. Por. też Alcinoos, Didaskalikos, VIII; Apuleius, De Platone et eius dogmate, V, 190-192.

29 More on the discussion about eternity of the world and about the different meanings

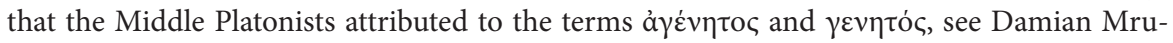
galski, "Stwarzanie wieczne i poza czasem. Filozoficzne źródła koncepcji generatio aeterna Orygenesa”, Verbum Vitae 35 (2019): 367-412.

${ }^{30}$ Cf. Albinus, Fr. 12-13 (ed. Vimercati, 392-394).

31 Cf. idem, Fr. 12 (ed. Vimercati, 394). 
it did not necessarily appear in time. In this sense, according to him, the world is created ( $\gamma \varepsilon v \eta \tau$ tó), and yet eternal ${ }^{32}$. Taurus is aware that some Platonists consider matter to be one of the cosmogenic principles (next to the ideas and the Demiurge). However, he states that "it should not be called

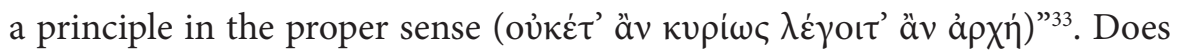
this mean that it was created by God and then transformed into the visible world? We do not fully know this, although it is worth mentioning that this philosopher, like Eudorus of Alexandria, suggested that Plato spoke of some supreme metaphysical principles to those who were able to understand it, while to those less intelligent he spoke of other principles. Thus, he suggested to some of his listeners that the world was ungenerated, although it had come from supreme causes, while to others - that the world was generated and he indicated other causes of its generation ${ }^{34}$.

Although neither Calvenus Taurus nor Albinus speak unambiguously (at least in the preserved fragments) when it comes to the creation of matter, we are in possession of a very interesting but rather general testimony of a dispute that was held at that time. In his Commentary on Plato's Timaeus, the Neoplatonic Proclus informs us that there was an ongoing debate among the philosophers of Middle Platonism, not only with regard to the eternity of the world, but also to the origin of matter. Here is his statement:

One may ask with regard to matter itself whether it is ungenerated by any cause

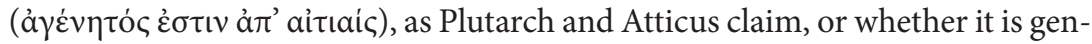

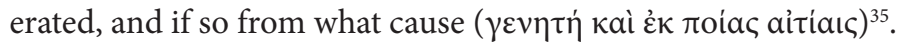

We know that Plutarch and Atticus, mentioned here by Proclus, were among the few Middle Platonists who interpreted Plato's Timaeus literally

32 Cf. Calvenus Taurus, Fr. 23 (ed. Vimercati, 504). Taurus lists a few other meanings of the term $\gamma \varepsilon v \eta \tau$ 'o $\varsigma$ which, according to him, can be found in Plato's dialogues. None of them, however, refers to the temporal order. For more on the subject see Franco Ferrari, "Lucio Calveno Tauro e l'interpretazione didascalica della cosmogenesi del Timeo", in: KA $\Lambda O \Sigma$ KAI APETH. Bellezza e virtù. Studi in onore di Maria Barbanti, ed. R. Loredana Cardullo et al. (Acireale-Roma: Bonanno, 2014), 321-333.

${ }_{33}$ Calvenus Taurus, Fr. 23 (ed. Vimercati, 504).

${ }^{34}$ Cf. idem, Fr. 26 (ed. Vimercati, 510).

35 Proclus, In Platonis Timaeum commentaria, II, 384, 2-5. 
and believed that the world was generated in time ${ }^{36}$. They also claimed in the same vein that, according to Plato, matter is eternal and uncreated. Alcinous, Severus, Celsus and the above-mentioned Eudorus of Alexandria, Albinus of Smyrna and Calvenus Taurus, all of them opted for an allegorical interpretation of Timaeus, i.e. for the eternal existence (or creation) of the world ${ }^{37}$. Although Proclus' testimony gives no names of any Platonists who, unlike Plutarch and Atticus, would claim that matter is created, it indicates such a possibility of interpreting Plato's Timaeus. We know Eudorus of Alexandria was explicitly in favour of the creation of matter. Did other proponents of Plato's allegorical interpretation, such as above-mentioned Albinus of Smyrna, Calvenus Taurus and other Middle Platonists, share his view?

The analysis carried out here shows that between the $1^{\text {st }}$ and $3^{\text {rd }}$ centuries A.D. there was an ongoing heated discussion not only about eternity of the world, but also about the quantity, hierarchy and reciprocal origin of the metaphysical principles mentioned by Plato in his dialogues. The fact that many Middle Platonists list God, ideas, and matter as principles does not mean that everyone unanimously recognizes these principles as equally eternal. It is also possible that there are the One and the Indefinite Dyad above them which are the cause of the multiplicity of ideas. The latter, in turn, are the formal cause of material beings. Moreover, above the One acting upon the Dyad, there may be one another, more transcendent principle, which Plato spoke about in his unwritten teachings. For Eudorus, this principle was supreme God - the One, from whom absolutely everything including matter is derived. His opinions were certainly not shared by Plutarch and Atticus, but were they shared by other Middle Platonists?

${ }^{36}$ Cf. Plutarchus, De animae procreatione in Timaeo, 1013a-b; 1014a-b; Atticus, Fr. 4 (ed. Vimercati, 734-742); idem, Fr. 19-25 (ed. Vimercati, 768-772). On the interpretations of Plato's Timaeus by Plutarch and Atticus see Franco Ferrari, "Materia, movimento, anima e tempo prima della nascita dell'universo. Plutarco e Attico sulla cosmologia del Timeo", in: De l'Antiquité tardive au Moyen Âge, ed. Elisa Coda et al. (Paris: Vrin, 2014), 255-276.

37 Cf. Alcinoos, Didaskalikos, XIV; Severus, Fr. 6-7 (ed. Vimercati, 538-540); Celsus, in: Origenes, Contra Celsum, I, 19; Eudorus, Fr. 6 (ed. Vimercati, 82-86); Albinus, Fr. 12-13 (ed. Vimercati, 392-394); Calvenus Taurus, Fr. 25-28 (ed. Vimercati, 508-516). On the dispute over the eternal nature of the world among the Middle Platonists see Giovanni Reale, Storia della filosofia greca e romanta, vol. 7: Rinascita del Platonismo e del Pitagorismo, Corpus Hermeticum e Oracoli Caldaici (Milano: Bompiani, 2010), 141-154. 


\section{Plato and Moses: The Voice of Christian Middle Platonists}

Christian thinkers of the $2^{\text {nd }}$ and $3^{\text {rd }}$ centuries A.D. also take their place in this complicated mosaic of theses and views on the first metaphysical principles presented by the Middle Platonists ${ }^{38}$. It is true, as Gerhard May claims, that some of them occasionally copied Plato's theses. In my opinion, however, they did not necessarily do so in an inconsiderate manner. Let us take a closer look at two seemingly similar and yet different statements made by Justin Martyr ( $2^{\text {nd }}$ century A.D.) and the author of Cohortatio ad Graecos ( $3^{\text {rd }}$ century A.D.) mistakenly identified with Justin. Using the argument about the so-called furta Graecorum, which was popular at that time, they both claim that Plato read Moses and drew his doctrine about creation of the world from him. However, Justin believes Plato understood Moses ${ }^{39}$ while Pseudo-Justin believes Plato misunderstood Moses $^{40}$. This understanding or misunderstanding, apart from the tendentious apologetic argument, is in both cases connected with choosing one of Plato's Middle Platonic interpretations. According to Justin, the world is not eternal but was created from pre-existing matter ${ }^{41}$. In this statement, he follows the interpretation by Plutarch and Atticus, although he is also familiar with the views on the subject presented by other Middle Platonists ${ }^{42}$. The author of Cohortatio ad Graecos, on the other hand, proves that Plato has gone astray by formulating his doctrine of pre-existing separate forms and of ungenerated matter, although he is also

${ }^{38}$ In these thinkers circle we can enumerate, besides others, the following: Athenagoras, Justin Martyr, the author of Cohortatio ad Graecos, or Clement of Alexandria. For more on their connections with the philosophy of Middle Platonism see Salvatore Lilla, Clement of Alexandria. A Study in Christian Platonism and Gnosticism (Oxford: Oxford University Press, 1971); idem, Introduzione al Medio platonismo, 111-135.

39 Cf. Iustinus, Apologia, I, 59, 1-5.

40 Cf. Pseudo Iustinus, Cohortatio ad Graecos, 29, 1-30, 4.

${ }^{41}$ This does not mean, however, that, according to Justin, this pre-existing matter was not previously created by God. Perhaps, in harmony with Gen. 1:1: "In the beginning God created the heaven and the earth", God first creates the pre-existing material and then, in the subsequent days of creation (cf. Gen 1:6-26) organizes what He had created on the first day. Cf. O’Neil, "How Early is the Doctrine of Creatio ex Nihilo?", 454-455.

${ }^{42}$ Cf. Iustinus, Dialogus cum Tryphone, 5, 1. See also Lilla, Introduzione al Medio platonismo, 130-132. 
familiar with a different Middle Platonic solution to this question ${ }^{43}$. It is also worth noting that Pseudo-Justin, like Philo of Alexandria ${ }^{44}$, notices the difference between the Demiurge and the Creator, and even clearly explains this difference:

For the Creator creates the creature by his own capability and power ( $\dot{\varepsilon} \kappa \tau \tilde{\eta} \varsigma$

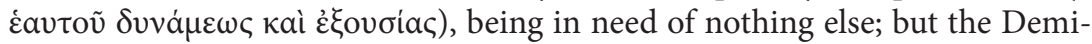

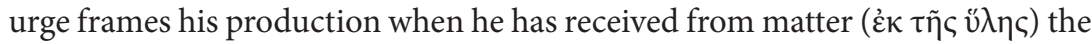
capability for his work ${ }^{45}$.

The author of Cohortatio ad Graecos continues to argue that "he who has not created has no power, in respect of that which is uncreated" 46 . Thus, if matter were ungenerated and co-eternal to God, He would have no power over $\mathrm{it}^{47}$. Therefore, he recognizes supreme God as the highest and the only principle of creation ${ }^{48}$.

Clement of Alexandria ( $2^{\text {nd }} / 3^{\text {rd }}$ century A.D.) joins the Middle Platonic discussion on the first metaphysical principles. Also he, like Justin and the author of Cohortatio ad Graecos, believes that Plato learned his doctrine on the origins of the world from Moses $^{49}$. However, the question arises whether Plato understood Moses well. As for the theory of ideas, he surely did so, because, as the Alexandrian argues, he read in Genesis that "In the beginning God

${ }^{43}$ Cf. Pseudo Iustinus, Cohortatio ad Graecos, 7, 1.

${ }^{44}$ Cf. Philo, De somniis, I, 76, cited above.

45 Pseudo Iustinus, Cohortatio ad Graecos, 22, 4.

46 Ibidem, 23, 2.

${ }^{47}$ Cf. ibidem. A similar statement can also be found in Philo, although the latter, instead

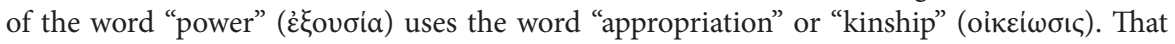
which is not created, argues the Alexandrian, has no kinship or is not the property of the one who did not create it. But God created the world and has power over it. See Philo, De opificio mundi, 10.

${ }^{48}$ It is worth adding that Pseudo-Justin, like other Middle Platonists, also mentions "the first God" ( $\pi \rho \tilde{\omega} \tau o \varsigma, \theta \varepsilon o ́ \varsigma)$. See Pseudo Iustinus, Cohortatio ad Graecos, 6, 1. This mention is considered to be Plato's own view, just like the earlier quoted statements concerning matter (generated and ungenerated). In fact, Cohortatio ad Graecos is a lecture on various doctrines which are attributed mainly to Plato but also to Aristotle, which clearly reveals the author's dependence on the Middle Platonic doctrines. Cf. Lilla, Introduzione al Medio platonismo, 133-135.

49 Cf. Clemens, Stromata, V, 92, 1-4. 
created the heaven and the earth; and the earth was invisible (áópatoc)" ${ }^{50}$. This invisible world was interpreted by Plato as the world of intelligible archetypes on the basis of which God creates visible entities ${ }^{51}$. However, Clement is not unambiguous about the pre-existing matter from which the world is to be created. In fact, in one passage, he suggests that the same sentence

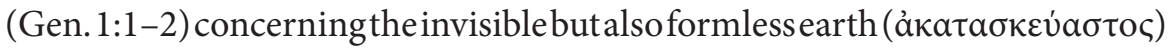
was an inspiration for philosophers for the doctrine of pre-existing matter ${ }^{52}$, although he does not explain exactly what he thinks about it. Elsewhere he states:

God has no connection with us with regard to nature, as the authors of heresies maintain (neither if he creates out of nothing, nor if he creates out of matter, since non-being does not exist at all, and matter is completely different from God). Unless someone dare say that we are part ( $\mu \dot{\varepsilon} \rho))$ of God and consub-

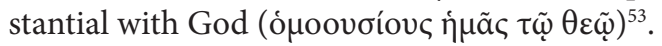

The doctrine of consubstantiality of some people with God was preached by the Gnostics. And only this view is rejected by Clement. The other two theories, i.e. the one that proclaims that the world was created out of nothing ( $\dot{\varepsilon} \kappa \mu \grave{\eta}$ ö $v \tau \omega \nu)$ and the one according to which the world was created from matter ( $\dot{\xi} \xi \ddot{v} \lambda \eta \varsigma)$ are, according to the Alexandrian thinker, acceptable. Why? Because both assume the primacy and transcendence of the supreme principle of creation which is God. Matter, which Clement notes elsewhere, is even considered by Plato himself to be non-being ( $\mu$ 门̀ ö $v$ ), by which he pointed out that the true and really existing first principle is one ( $\mu$ ía ö $v \tau \omega \varsigma$

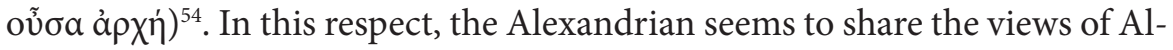
binus and Taurus, which we discussed above. Only God is the proper and truly eternal principle of the creation of the world. Therefore, in the Stromata, He is called "the cause beyond causes" (

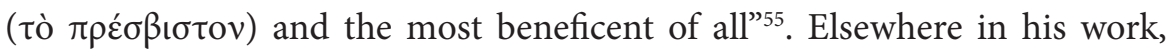

\footnotetext{
50 Gen. 1,1-2 (according to LXX). Cf. Clemens, Stromata, V, 94, 1.

51 Cf. Clemens, Stromata, V, 94, 2-3.

52 Cf. ibidem, V, 90, 1.

53 Ibidem, II, 74, 1.

${ }^{54}$ Cf. ibidem, V, 89, 7.

55 Ibidem, VII, 2, 3.
} 
Clement, like Eudorus of Alexandria, identifies God with the transcendent

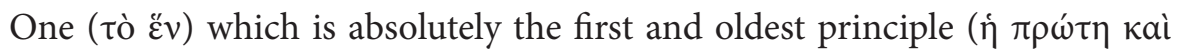
$\left.\pi \rho \varepsilon \sigma \beta v \tau \alpha^{\prime} \tau \eta ~ \dot{\alpha} \rho x \eta \dot{)}\right)$, which is the cause of all other things being and having been $^{56}$. The One is infinite in its essence ${ }^{57}$, but also in its power, for it is Its nature to do good all the time, "just as the nature of fire is to warm, and the nature of light is to shine" ${ }^{18}$. Since all things come from the infinite One-Good, there can be no other principle of the creation of the world, as Clement suggests also in the place where he speaks of Plato's plagiarism mentioned above:

The philosophers took the doctrine that the world was generated also from Moses. For Plato speaks openly: "Did the world exist eternally, having no principle of generation, or has it come into being, starting from some principle? It has come into being, since, being visible, it is also tangible, and being tangible, it possesses a body" ${ }^{59}$. Immediately after that, he said: "But the Father and Maker of all this universe it is a hard task to find" ${ }^{\prime \prime}$. Not only does he prove here that the world has been generated, but he also shows that the world was generated by God as a son, and that God is called its Father, because it came

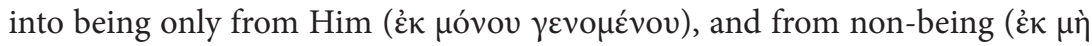

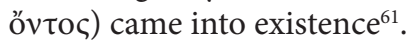

It is worth noting, first of all, that Clement quotes a text from Timaeus $28 \mathrm{~b}$ which for the Middle Platonists was of key importance. It was around this text that the debate on eternity of the world took place. Although in his interpretation of Plato's statement, the Alexandrian philosopher seems to take the side of Plutarch and Atticus because, like them, he believes that the world has come into being and is generated; yet, he does not want to say that matter from which the world has been created is ungenerated, as the others maintained. After all, only God himself is defined as the only one ( $\mu$ óvoৎ) principle of the creation of the world. Clement, therefore, is closer to the view of the Middle Platonists who regarded the transcendent One as the supreme

\footnotetext{
56 Cf. ibidem, V, 81, 4-6.

57 Cf. ibidem.

58 Ibidem, I, 86, 3. See also ibidem, II, 5, 5; VI, 47, 3-4.

59 Plato, Timaeus, $28 \mathrm{~b}$.

60 Ibidem, 28c.

${ }^{61}$ Clemens, Stromata, V, 92, 1-4.
} 
principle, from which absolutely everything, including matter, derives. Thus, he postulates the doctrine of creatio ex nihilo, as indicated by the last sentence of the above quotation. In this context, the formula: $\dot{\kappa} \kappa \mu \grave{\eta}$ ö $v \tau o \varsigma$ no longer refers to pre-existing matter but to absolute non-being ${ }^{62}$.

Origen of Alexandria, who lived a little later $\left(2^{\text {nd }} / 3^{\text {rd }}\right.$ century A.D. $)$, also believed that Plato knew Moses, or at least that during his trip to Egypt he met "people who philosophically interpreted Jewish scriptures" and took possession of many of them ${ }^{63}$. As far as creatio ex nihilo is concerned, Origen considered this concept to be traditional teaching of the Church ${ }^{64}$. He even quoted some biblical and patristic formulas, which points to the ancient origins of such a tradition ${ }^{65}$. As in the case of his predecessor of Alexandria, his doctrine of creation out of nothing is a contribution to the Middle Platonic debate on eternity of the world and matter:

This matter, then, which is so great, and such that it is able to suffice for all bodies in the world that God willed to exist and to attend upon and serve the Creator for whatever forms and species he wished in all things, receiving into itself whatever qualities he wished to bestow upon it - I do not understand how so many and such distinguished men have held it to be uncreated, that is, not made by God himself, the creator of all things, but that its nature and power were the result of chance. And I am astonished that they should find fault with those who deny that God is the maker of the universe or his providential administration of it, and accuse of impiety those who think that such a great work as the world could exist without a maker or overseer, while they themselves incur a similar charge for saying that matter is uncreated and coeternal with the uncreated God ${ }^{66}$.

${ }^{62}$ Cf. Matteo Monfrinotti, Creatore e creazione. Il pensiero di Clemente Alessandrino (Roma: Città Nuova, 2014), 178.

${ }_{63}$ Origenes, Contra Celsum, IV, 39. According to Origen, when Plato was composing his works, he changed what he took from Moses in order not to disgust the Greeks who had a negative attitude towards Jews and their laws. Cf. ibid.

${ }^{64}$ Cf. idem, De principiis, Praefatio, 4.

${ }^{65}$ Cf. idem, De principiis, I, 3, 3; II, 1, 5; idem, Commentarius in Joannem, I, 17, 103. In the places indicated here Origen refers, among others, to the Second Maccabees (7:28), the apocryphal Book of Henoch (2-5) and the Shepherd of Hermas (1:6; 26:1).

${ }^{66}$ Origenes, De principiis, II, $1,4$. 
In the first part of the above statement, Origen, sharing the opinions of the Middle Platonists, claims that the creation of the visible world consisted in imposing forms and species (formas ac species) on pre-existing matter. Moreover, he attributes to matter the same properties that are also mentioned in the texts of the Middle Platonic philosophers. It is therefore a substrate without quality ( $\ddot{\alpha} \operatorname{toto} \varsigma$ = sine qualitatibus), changeable, mutable, and capable of receiving into itself any form that the Creator wishes to bestow upon it ${ }^{67}$. In the second part of the quoted text, however, the Alexandrian disagrees with those philosophers who consider matter to be ungenerated (á) dence and omnipotence, as we learn later in the same chapter of the work On First Principles ${ }^{68}$. God has absolute power over matter precisely because it was created by Him. It is not equal to God, nor is it evil created by God. It is simply a substrate subordinate to its Creator in everything ${ }^{69}$. Philosophers such as Aristotle and the Epicureans denied the providential activity of God in the world. The Middle Platonists, especially those who considered the world to have been generated, opposed to their views ${ }^{70}$. Defending the concept of divine providence, they argued that the world must have been generated; otherwise, if deprived of its Creator, it would have no Overseer. Origen, knowing and agreeing with these arguments, went further. Not only the world, but also the matter from which it came into being must be considered created. Otherwise, one would remain halfway down the path leading to demonstrating God's omnipotence and His providential rule over the world, or even make the very same mistake one criticises.

${ }^{67}$ Cf. idem, Contra Celsum, III, 41; IV, 57; idem, Commentarius in Joannem, XIII, 21, 127; idem, De principiis, III, 6, 7; IV, 4, 6-7.

${ }_{68}$ Cf. idem, De principiis, II, 1, 4.

${ }^{69}$ Cf. ibidem.

${ }^{70}$ Cf. Atticus, Fr. 3-4 (ed. Vimercati, 728-740); Philo, De opificio mundi, 7-11, where we can find arguments similar to those presented by Origen. It should be noted, however, that other Middle Platonists have also criticized Aristotle and Epicurus for rejecting the doctrine of divine providence. Among them were those who considered the world to be ungenerated. After all, as we have shown above, "ungenerated" may simply mean "eternal" and eternally dependent upon the supreme cause, which is God. Cf. e.g. Calvenus Taurus, Fr. 18 (ed. Vimercati, 496); idem, Fr. 26-27 (ed. Vimercati, 510-514); Numenius, Fr. 52 (ed. Vimercati, 1442-1449); Alcinoos, Didaskalikos, XII; Apuleius, De Platone et eius dogmate, XII, 205-206. 
The Alexandrian therefore examines the theses of the Middle Platonists; sometimes he supplements them, but sometimes he simply has to agree with them. This is especially noticeable in the passages in which he discusses the question of the immutability and goodness of God, to which the Middle Platonic doctrine of eternity of the world is connected:

But they are wont to object, saying, "If the world began in time, what was God doing before the world began? For it is at once impious and absurd do say that the nature of God is inactive and immobile, or to suppose that goodness at one time did not do good and omnipotence at one time did not exercise its power". Such is the objection they are accustomed to make when we say that this world began at a definite time and when we count the years of its age according to the assurance of Scripture ${ }^{71}$.

The response to such an objection is Origen's hypothesis of the succession of subsequent worlds ${ }^{72}$ and the concept of eternal creation of the world in the Logos, identified with God's Wisdom ${ }^{73}$. In this Wisdom there have always existed general ideas (genera and species), but also spiritual individuals ${ }^{74}$. After all, if God is almighty and good, as Origen argues, then He has always needed to have someone to exercise His power over and give His benefits to ${ }^{75}$. Difficult as it may be for human reason to understand, he notes, "ever since God existed, there also have been His creatures (semper ex quo deus est fuisse etiam creaturas)" ${ }^{\prime \prime}$. The archetypes existing in God's Wisdom therefore precede the creative act only logically, not chronologically ${ }^{77}$, exactly as the Middle Platonists, or at least Albinus or Taurus, postulated for, according to Origen, one cannot imagine a moment when God was neither creator, nor benefactor,

71 Origenes, De principiis, III, 5, 3.

72 Cf. ibidem. See also ibidem, II, 3, 1-5.

73 Cf. idem, In Genesim homiliae, 1, 1; idem, De principiis, I, 2, 10; I, 4, 3-5. See also Mrugalski, "Stwarzanie wieczne i poza czasem", 390-402.

${ }^{74}$ Cf. idem, De principiis, I, 4, 5.

75 Cf. ibidem, I, 2, 10.

76 Ibidem, I, 4, 4.

77 Cf. Gaetano Lettieri, "Il voṽ nel Commento a Giovanni", in: Il Commento a Giovanni di Origene: Il testo e i suoi contesti, ed. Emanuela Prinzivalli (Villa Verucchio: Pazzini Editore, 2005), 239. 
nor provident ${ }^{78}$. And what about matter? Did it also exist before the creation of this visible world? The Alexandrian answers paradoxically - yes. Matter in various forms has accompanied the created rational beings since always. "The material substance", Origen states, "is to be separated from them only in thought and understanding"79. Only the Trinity is absolutely incorporeal and only the Trinity transcends all time and even eternity ${ }^{80}$.

Origen seems to share the ideas of the Middle Platonists concerning eternity of the world, although he does not agree with the terminology used by

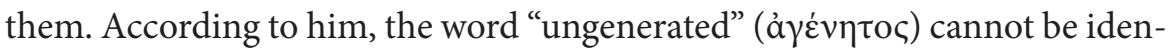

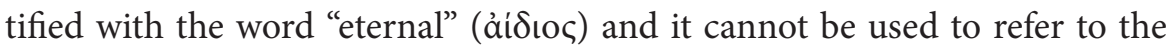
world as Taurus and Albinus did. According to the thinker of Alexandria, the world and matter were created; moreover, they were created ex nihilo. As created, they exist in time, which does not exclude this time from being everlasting ${ }^{81}$. God, who transcends all time, can everlastingly create things, over which He exercises His power and over which He grants His benefits. Therefore, it is only about God, or rather only about the Father, that one can say He is ungenerated (ảy $\dot{\varepsilon} v \eta \tau o \varsigma)$. For Logos has already been generated, although its metaphysical status is still different from that of the creatures. For it is generated out of the substance of the Father, without any temporal moment, and while remaining permanently united with the Father, He also transcends all time and all eternity ${ }^{82}$.

78 Cf. Origenes, De principiis, I, 4, 3.

79 Ibidem, II, 2, 2. See also ibidem, II, 3, 3; IV, 4, 6.

80 Cf. ibidem, IV, 4, 1.

${ }^{81}$ It should be noted, however, that researchers are divided when it comes to understanding time and eternal creation in Origen. Their opinions largely depend upon whether they agree to a greater or lesser extent with influence of Platonism on the doctrine of the Alexandrian. For more on the subject see Carl S. O'Brien, The Demiurge in Ancient Thought: Secondary Gods and Divine Mediators (Cambridge: Cambridge University Press, 2015), 244-289; Panayiotis Tzamalikos, Origen: Cosmology and Ontology of Time (Leiden: Brill, 2006), 21-175; Lettieri, "Il voũ mistico", 235-242.

82 Cf. Origenes, Commentarius in Joannem, I, 29, 204; II, 1, 8-9; II 2, 18. 


\section{Conclusions}

The above analyses show that the doctrine of creating the world out of nothing is gradually shaped within the debates of the Middle Platonists on the first metaphysical principles. It is therefore not true, as Gerhard May suggests, that it appeared for the first time in Basilides ( $2^{\text {nd }}$ century A.D.) and, as a doctrine of the Church, it became established when Christian thinkers discovered the disastrous influence of Platonic theses which they initially copied without reflection. For already at the end of the $1^{\text {st }}$ century B.C., the pagan philosopher Eudorus of Alexandria believed that supreme God - the One, is the cause of the existence of all beings, including matter. It is true that as cosmogenic principles other Middle Platonists indicated God, ideas, and matter, but they did not always consider the latter to be a principle in the proper sense. Among the philosophers of Middle Platonism there were those who, interpreting Plato's Timaeus literally, believed that the world had come into being in time and that it had emerged from uncreated matter. However, there were also those who, interpreting Plato's dialogue allegorically, believed that the world had existed eternally, although it always depended on God, who was the "older" and eternal cause "in the primordial sense".

Christian thinkers of the first three centuries A.D. did not follow unthinkingly one of these interpretations. As we have tried to demonstrate, they took the respective theses of the various groups of the Middle Platonists seriously, although their argumentation was sometimes based on a tendentious apologetic thesis that Plato had derived his doctrine on the creation of the world from Moses. Thus, although Clement seems to support Plutarch's and Atticus' interpretation of the creation of the world in time, he does not claim that matter is uncreated. Like Eudorus of Alexandria, he believes everything, including matter, derives from the transcendent One which is the "cause beyond causes" and the "oldest" cause. Also Origen, although he believes that the world was created out of nothing, examines attentively the arguments of the Middle Platonists that postulate the eternal existence of the world and matter. Not only does he examine them, but he also agrees with the argumentation related to the immutability, goodness, 
providence, and omnipotence of God. Ultimately, he states that there have always been creatures over which God has exercised His power. Thus, the concept of eternal creation out of nothing is formulated.

Let us finally add that both thinkers were very well familiar with the theories of the Gnostics. After all, it is their works that are the source of knowledge about Gnosticism for us today. However, the doctrine of creatio ex nihilo does not appear in their works as a reaction to the theses put forward by Gnostics who, taking over Platonic cosmology, deformed the Christian doctrine of creation. As we have demonstrated, it is rather the result of a constructive reflection on the debate of Middle Platonic philosophers at that time.

\section{Bibliography}

\section{Ancient Sources}

Albinus. 2015. "Fragmenta". In: Medioplatonici: opere, frammenti, testimonianze. Testi greci e latini a fronte. Ed. E. Vimercati, 386-399. Milano: Bompiani.

Alcinoos. 1990. "Didaskalikos". Alcinoos. Enseignement des doctrines de Platon. Introduction, Texte établi et commenté. Ed. J. Whittaker. Paris: Les Belles Lettres.

Apuleius. 1991. "De Platone et eius dogmate". Apulei Platonici Madaurensis opera quae supersunt. Vol. 3: De philosophia libri. Ed. C. Moreschini. Stutgardiae-Lipsiae: Teubner.

Atticus. 2015. "Fragmenta". In: Medioplatonici: opere, frammenti, testimonianze. Testi greci e latini a fronte. Ed. E. Vimercati, 718-790. Milano: Bompiani.

Calvenus Taurus. 2015. "Fragmenta". In: Medioplatonici: opere, frammenti, testimonianze. Testi greci e latini a fronte. Ed. E. Vimercati, 464-530. Milano: Bompiani.

Clemens. 1951-2001. "Stromata". In: Clément d’Alexandrie. Stromate (SCh 30, 38, 278, 428, 446, 463). Ed. C. Mondésert, M. Caster, P. T. Camelot, A. Le Boulluec, P. Voulet, P. Descourtieux, A. Van Den Hoeck. Paris: Cerf.

Eudorus. 2015. "Fragmenta". In: Medioplatonici: opere, frammenti, testimonianze. Testi greci e latini a fronte. Ed. E. Vimercati, 74-139. Milano: Bompiani.

Iustinus. 1994. "Apologia". In: Iustini Martyris Apologiae pro Christianis. Ed. M. Marcovich. Berlin-New York: Walter de Gruyter.

Iustinus. 1997. "Dialogus cum Tryphone". In: Iustini Martyris Dialogus cum Tryphone. Ed. M. Marcovich. Berlin-New York: Walter de Gruyter. 
Numenius. 2015. "Fragmenta". In: Medioplatonici: opere, frammenti, testimonianze. Testi greci e latini a fronte. Ed. E. Vimercati. 1362-1461. Milano: Bompiani.

Origenes. 1966-1992. "Commentarius in Joannem". In: Origène. Commentaire sur saint Jean (SCh 120, 157, 222, 290, 385). Ed. C. Blanc, Paris: Cerf.

Origenes. 1967-1969. "Contra Celsum”. In: Origène. Contre Celse (SCh 132, 136, 147, 150). Ed. M. Borret. Paris: Cerf.

Origenes. 1978-1980. "De principiis". In: Origène. Traité des principes (SCh 252, 268). Ed. H. Crouzel, M. Simonetti. Paris: Cerf.

Origenes. 1976. "In Genesim homiliae". In: Origène. Homélies sur la Genèse (SCh 7bis). Ed. H. de Lubac, L. Doutreleau. Paris: Cerf.

Philo. 1981-1999. “Opera”. Philo in Ten Volumes (LCL 226-227, 247, 261, 275, 289, 320, 341, 363, 379). Ed. G. P. Goold, transl. F. H. Colson, G. H. Whitaker. Cambridge-London: Harvard University Press.

Plato. 1931-1934. "Respublica". In: Plato, Oeuvres Complètes. Vol. VI, VII/1, VII/2. Ed. E. Chambry. Paris: Les Belles Lettres.

Plato. 1925. “Timaeus”. In: Plato, Oeuvres Complètes. Vol. X. Ed. A. Rivaud. Paris: Les Belles Lettres.

Plutarchus. 2017. "De animae procreatione in Timaeo". In: Plutarco, Tutti i Moralia. Prima traduzione italiana completa. Testo greco a fronte. Ed. E. Lelli, G. Pisani. 1958-1993. Milano: Bompiani.

Proclus. 1903-1904. "In Platonis Timaeum commentaria". In: Procli Diadochi in Platonis Timaeum commentaria. Vol. 1-2. Ed. E. Diehl. Lipsiae: B. G. Teubneri.

Pseudo Iustinus. 1990. "Cohortatio ad Graecos". In: Pseudo-Iustinus. Cohortatio ad Graecos. De monarchia. Oratio ad Graecos. Ed. M. Marcovich, 23-78. BerlinNew York: Walter de Gruyter.

Severus. 2015. "Fragmenta". In: Medioplatonici: opere, frammenti, testimonianze. Testi greci e latini a fronte. Ed. E. Vimercati, 536-552. Milano: Bompiani.

\section{Secondary Works}

Bockmuehl Markus. 2012. "Creatio ex Nihilo in Palestinian Judaism and Early Christianity”. Scottish Journal of Theology 65: 253-270.

Copan Paul, William L. Craig. 2004. Creation Out of Nothing: A Biblical, Philosophical, and Scientific Exploration. Grand Rapids: Baker Academic.

Copan Paul. 1996. "Is Creatio ex Nihilo a Post-Biblical Invention? An Examination of Gerhard May's Proposal". Trinity Journal 17: 77-93.

Dillon John. 1996. The Middle Platonists: 80 B.C. to A.D. 220. Ithaca: Cornell University Press.

Ferrari Franco. 2012. "L'esegesi medioplatonica del Timeo: metodi, finalità, risultati". In: Il Timeo. Esegesi greche, arabe, latine. Ed. Francesco Celia, Angela Ulacco, 81-131. Pisa: Plus-Pisa University Press. 
Ferrari Franco. 2014. "Lucio Calveno Tauro e l'interpretazione didascalica della co-

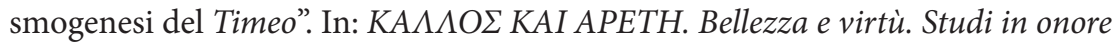
di Maria Barbanti. Ed. R. Loredana Cardullo, Daniele Iozzia, 321-333. AcirealeRoma: Bonanno.

Ferrari Franco. 2014. "Materia, movimento, anima e tempo prima della nascita dell'universo. Plutarco e Attico sulla cosmologia del Timeo". In: De l'Antiquité tardive au Moyen Âge. Ed. Elisa Coda, Cecilia Martini Bonadeo, 255-276. Paris: Vrin.

Ferrari Franco. 2015. "Metafisica e teologia nel medioplatonismo", Rivista di storia della filosofia 70: 321-337.

Lettieri Gaetano. 2005. "Il voṽ nel Commento a Giovanni". In: Il Commento a Giovanni di Origene: Il testo e i suoi contesti. Atti dell'VIII Convegno di Studi del Gruppo italiano di ricerca su Origene e la Tradizione alessandrina (Roma 28-30 settembre 2004). Ed. Emanuela Prinzivalli, 177-275. Villa Verucchio: Pazzini Editore.

Lilla Salvatore. 1971. Clement of Alexandria. A Study in Christian Platonism and Gnosticism. Oxford: Oxford University Press.

Lilla Salvatore. 1992. Introduzione al Medio platonismo. Roma: Istituto Patristico Augustinianum.

May Gerhard. 1978. Schöpfung aus dem Nichts: Die Entstehung der Lehre von der creatio ex nihilo. Berlin: Walter de Gruyter.

May Gerhard. 2004. Creatio ex Nihilo: The Doctrine of "Creation out of Nothing" in Early Christian Thought, transl. A. S. Worrall. London: T\&T Clark International.

McMullin Ernan. 2010. "Creation ex Nihilo: Early History". In: Creation and the God of Abraham. Ed. David B. Burrell, Carlo Cogliati, Janet M. Soskice, William R. Stoeger, 11-23. Cambridge: Cambridge University Press.

Monfrinotti Matteo. 2014. Creatore e creazione. Il pensiero di Clemente Alessandrino. Roma: Città Nuova.

Mrugalski Damian. 2013. Il Dio trascendente nella filosofia alessandrina giudaica e cristiana: Filone e Clemente. Roma: Angelicum University Press.

Mrugalski Damian. 2019. "Stwarzanie wieczne i poza czasem: Filozoficzne źródła koncepcji generatio aeterna Orygenesa”. Verbum Vitae 35: 367-412.

Niehoff Maren R. 2006. "Creatio ex Nihilo Theology in Genesis Rabbah in Light of Christian Exegesis". Harvard Theological Review 99: 37-64.

O'Brien Carl S. 2015. The Demiurge in Ancient Thought: Secondary Gods and Divine Mediators. Cambridge: Cambridge University Press.

O’Neil John C. 2002. "How Early is the Doctrine of Creatio ex Nihilo?". Journal of Theological Studies 58: 449-465.

Reale Giovanni. 1979. "Filone di Alessandria e la prima elaborazione filosofica della dottrina della creazione". In: Paradoxos politeia. Studi patristici in onore di Giu- 
seppe Lazzati. Ed. Raniero Cantalamessa, Luigi F. Pizzolato, 247-287. Milano: Vita e Pansiero.

Reale Giovanni. 2010. Per una nuova interpretazione di Platone alla luce delle "dottrine non scritte". Milano: Bompiani.

Reale Giovanni. 2010. Storia della filosofia greca e romanta. Vol. 7: Rinascita del Platonismo e del Pitagorismo, Corpus Hermeticum e Oracoli Caldaici. Milano: Bompiani.

Richard Marie-Dominique. 2005. L'enseignement oral de Platon. Une nouvelle interprétation du platonisme. Paris: Cerf.

Runia David T. 1999. "A Brief History of the Term Kosmos Noetos from Plato to Plotinus". In: Traditions of Platonism. Essays in Honour of John Dillon. Ed. John J. Cleary, 151-171. Aldershot: Ashgate.

Sterling Gregory E. 2017. "The Most Perfect Work: The Role of Matter in Philo of Alexandria". In: Creation "ex nihilo": Origins, Development, Contemporary Challenges. Ed. Gary A. Anderson, Markus Bockmuehl, 99-118. Notre Dame: University of Notre Dame Press.

Tzamalikos Panayiotis. 2006. Origen: Cosmology and Ontology of Time. Leiden: Brill. Vimercati Emmanuele, Ed. 2015. Medioplatonici. Opere, frammenti, testimonianze. Testi greci e latini a fronte. Milano: Bompiani.

Young Frances. 1991. "Creatio Ex Nihilo: A Context for the Emergence of the Christian Doctrine of Creation". Scottish Journal of Theology 44: 139-152.

\begin{abstract}
Many Christian thinkers of the first centuries after Christbelieved - or apologetically postulated - that Plato would have read Moses, because, in his dialogue Timaeus, Plato included the biblical doctrine of the creation of the world. Some of them claimed that Plato understood what he read in Moses' writings, while others held that Plato did not really understand Moses, since Plato taught that the world was made of ungenerated matter. Both analyses fit into a broader context: the discussion among Middle Platonists surrounding the literal and allegorical interpretations of Timaeus. It is in this framework that the doctrine of the creation of the world from nothing (ex nihilo) appeared. The purpose of this article is to lay out the philosophical discussion about the origin of the world as it developed between the first and third centuries AD. In connection with this, we test the thesis of Gerhard May in his monograph Creatio ex nihilo, which claims that the doctrine of creation from nothing was established in the theology of the Church only after Christian thinkers perceived
\end{abstract}


the destructive influence of Plato's cosmological theories, which had led to the rise of Gnosticism.

Keywords: creation out of nothing, creatio ex nihilo, cosmology, Plato, Timaeus, Middle Platonism, Gnosticism, the influence of philosophy on Christianity, Patristic philosophy

Ministry of Science "Studies in the History of Philosophy" - publication of two foreign language issues of the and Higher Education magazine financed by Ministry of Science and Higher Education of the Republic of Poland on the basis of agreement no. 655/P-DUN/2019 (dated 7/05/19). 